\title{
Review of State Oil and Natural Gas Environmental Regulations
}

\section{Final Report}

DOE Interagency Agreement No.: DE-AI26-01BC15320

Period of Performance: April 1, 2001 to September 30, 2005

Prepared by:

Steve Souders

U.S. Environmental Protection Agency

Office of Solid Waste

Municipal and Industrial Waste Division

Washington, DC 20460

Submitted September 27, 2005 


\section{DISCLAIMER}

This report was prepared as an account of work sponsored by an agency of the United States Government. Neither the United States Government nor any agency thereof, nor any of their employees, makes any warranty, express or implied, or assumes any legal liability or responsibility for the accuracy, completeness, or usefulness of any information, apparatus, product, or process disclosed, or represents that its use would not infringe privately owned rights. Reference herein to any specific commercial product, process, or service by trade name, trademark, manufacturer, or otherwise does not necessarily constitute or imply its endorsement, recommendation, or favoring by the United States Government or any agency thereof. The views and opinions of authors expressed herein do not necessarily state or reflect those of the United States Government or any agency thereof. 


\section{ABSTRACT}

The State Review Process is a multi-stakeholder process administered by the State Review of Oil and Natural Gas Environmental Regulations (STRONGER), Inc. and is a continuation of work initiated by the Interstate Oil and Gas Compact Commission (IOGCC) in 1989.

The goal of the process is to assist oil and gas producing states in identifying innovative regulatory approaches to reducing environmental and administrative problems associated with the management of oil and gas exploration and production (E\&P) industry wastes and to comprehensively assess and improve implementation and enforcement of state regulatory programs.

The process consists of initial reviews of states' E\&P waste management regulatory programs by multi-stakeholder review teams and follow-up reviews to assess states' responses to the initial review teams' recommendations.

Participation of citizens' groups and environmental organizations in the state review process is encouraged and environmental training seminars are provided to citizens' groups and others who are concerned about E\&P waste management practices and interested in participating in state reviews. reviews.

To date, 20 state programs have been reviewed and nine of these states have had follow-up

The state review process has resulted in significant improvement to states' E\&P waste management regulatory programs and increased benefits to human health and the environment. 


\section{TABLE OF CONTENTS}

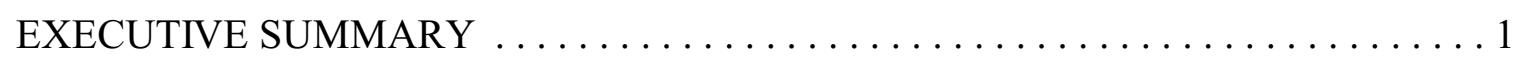

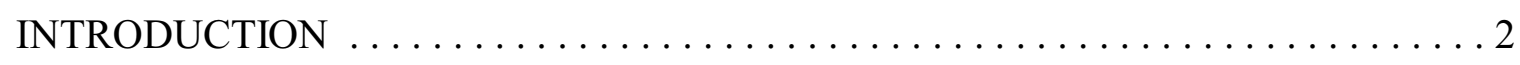

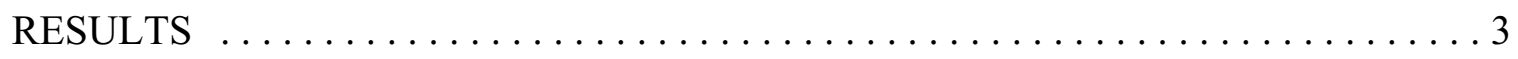

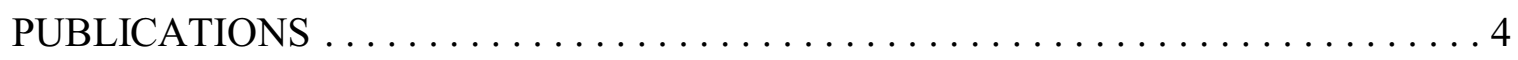

LIST OF ACRONYMS AND ABBREVIATIONS $\ldots \ldots \ldots \ldots \ldots \ldots \ldots \ldots \ldots 4$ 


\section{Executive Summary}

Since 1989 the U.S. Environmental Protection Agency (EPA) has supported a multistakeholder process to improve states' oil and gas exploration and production (E\&P) waste management regulatory programs. Other stakeholders involved in the process include environmentaland citizens groups, native American tribes, the Interstate Oil and Gas Compact Commission $^{1}$ (IOGCC), State Review of Oil and Natural Gas Environmental Regulations (STRONGER), Inc., the U.S. Department of Energy (DOE), the Bureau of Land Management and the American Petroleum Institute.

The purpose of this project was to continue and enhance the past efforts of the IOGCC, individual states, industry, public interest groups and EPA to improve state regulatory programs. Through an interagency agreement between DOE and EPA, DOE provided funding assistance to EPA. To achieve the project goals, these and additional funds were provided by EPA through grants to IOGCC and STRONGER to conduct multi-stakeholder evaluations of states' E\&P waste management regulatory programs.

The goal of the state review process is to assist oil and gas producing states in identifying innovative regulatory approaches to reducing environmental and administrative problems associated with the management of E\&P industry wastes and to comprehensively assess and improve implementation and enforcement of state regulatory programs.

States' programs are evaluated against a set of guidelines which were also developed through a multi-stakeholder process. The guidelines are also reviewed periodically and revised to reflect the emergence of additional regulatory issues.

Specific activities conducted thus far to achieve this goal include:

- $\quad$ Development of recommended state E\&P waste regulatory program guidelines through a multi-stakeholder process.

- $\quad$ Reviews of 20 state E\&P waste regulatory programs representing $95 \%$ of all U.S. onshore production of oil and natural gas.

- $\quad$ Follow-up reviews of nine state E\&P waste regulatory programs.

- $\quad$ Development and implementation of a training program for review team participants.

- Improvements in states' E\&P waste regulatory programs.

The project is on-going. The current project period expires September 30, 2005. Congress included a \$300,000 earmark in EPA's FY2005 budget for the STRONGER State Review Process. STRONGER has applied for a new grant from EPA to continue the project through September 2007.

\footnotetext{
${ }^{1}$ Formerly the Interstate Oil Compact Commission (IOCC).
} 


\section{INTRODUCTION}

Through 1980 amendments to the Resource Conservation and Recovery Act (RCRA), Congress temporarily exempted from the hazardous waste regulations under RCRA Subtitle C, drilling fluids, produced water and wastes associated with oil and gas exploration and production (E\&P) pending further study and a regulatory determination. EPA completed its study and published the results in December 1987 in a Report to Congress entitled "Management of Wastes from the Exploration, Development, and Production of Crude Oil, Natural Gas, and Geothermal Energy." Among other findings, EPA found that existing State and Federal regulations were generally adequate to manage oil and gas wastes, but that certain regulatory gaps did exist, and enforcement of existing regulations in some States was inadequate.

In July, 1988 EPA issued its regulatory determination (53 FR 25446) stating that federal regulation of oil and gas wastes as hazardous wastes was not warranted. At that time, EPA said it would implement a three-pronged strategy to address the diverse environmental and programmatic issues posed by these wastes. This strategy involved: (1) improving Federal programs under existing authorities in Subtitle D of RCRA, the Clean Water Act, and Safe Drinking Water Act; (2) working with States to encourage changes in their regulations and enforcement to improve some programs; and (3) working with Congress to develop any additional statutory authorities that may be required.

The State Review Process was proposed by the IOGCC in 1989 to address the second prong of EPA's strategy, to work with the states to improve their regulatory programs. The IOGCC was chartered by Congress in 1935 as the Interstate Oil Compact Commission and represents the governors of oil and gas producing states. IOGCC created the Council on Regulatory Needs, bringing together state, environmental, and industry representatives to develop national guidelines for state oil and gas programs which would be used as the criteria for state reviews. In early 1990, the Council released a document entitled "EPA/IOCC Study of State Regulation of Oil and Gas Exploration and Production Waste". This document established guidelines that represented the minimum acceptable criteria for regulatory programs. The Council also proposed to implement a process by which state oil and gas programs were reviewed in comparison with those guidelines.

In 1990, EPA provided a grant to the IOGCC to initiate state regulatory program reviews in comparison with the guidelines. Review teams were comprised of state regulatory officials, environmental representatives, and industry representatives. Representatives of other interested parties, such as federal agencies and tribal governments were invited to participate as official observers. State reviews were conducted in states that volunteered for review.

Recommendations were offered as blueprints for change to be considered by state legislators and regulators.

In 1998, a multi-stakeholder organization was formed by the state review program participants to revitalize and carry the state review program forward. This new organization is called State Review of Oil and Natural Gas Environmental Regulations, Inc. ("STRONGER"). STRONGER is a non-profit corporation that has been specifically formed to educate state regulators and the public as to the appropriate elements of a state E\&P waste management regulatory program, and to compare various state programs against guidelines adopted by the IOGCC for the protection of public health, safety and the environment.

STRONGER established five committees to review and update the 1994 version of the guidelines. STRONGER incorporated the consensus recommendations of the committees in this 
update, which has been reviewed by the IOGCC in draft, revised, and accepted by the IOGCC member states.

This DOE Interagency Agreement has provided financial assistance to STRONGER to organize and conduct state reviews and to IOGCC to assist states in completing the state review questionnaire. IOGCC has also participated in reviews as an official observer.

\section{RESULTS}

From 1990 through 1997, the IOGCC conducted, through a multi-stakeholder process, voluntary reviews of seventeen individual state regulatory programs for oil and gas exploration and production (E\&P) wastes. The states reviewed through 1997 include: Alaska, Arkansas, California, Colorado, Illinois, Kansas, Kentucky, Louisiana, New York, North Dakota, New Mexico, Ohio, Oklahoma, Pennsylvania, Texas, West Virginia, and Wyoming.

During the performance period of the DOE Interagency Agreement beginning in 2001, STRONGER has conducted, also through a multi-stakeholder process, voluntary reviews of three state E\&P waste regulatory programs - Indiana, Michigan and Virginia.

The initial review reports contain recommendations for action to the reviewed states. The reports also highlight strengths in a states' program. The recommendations, together with changes in the guidelines and changes in states' programs, provide the primary basis for follow-up reviews and follow-up recommendations to states.

STRONGER has also conducted follow-up reviews of nine states. California, Louisiana, New Mexico, Ohio, Oklahoma, Pennsylvania, Texas, West Virginia and Wyoming have had follow-up reviews to assess their progress in addressing the recommendations from their initial program reviews. The Pennsylvania follow-up review is the state's second follow-up review.

During this same period, IOGCC has assisted with reviews by recruiting volunteer states and assisting volunteer states with the completion of the state review questionnaire.

The states reviewed to date account for approximately $85 \%$ of the total U.S. onshore oil and gas wells and $95 \%$ of all onshore U.S. production of oil and natural gas. Many of the follow-up reviews show significant progress on making many changes recommended by the initial reviews. Further, after reviewing the recommendations posed in other states' reviews, many states have taken the initiative to make program changes without the "formality" of an external review.

Reviews of state oil and gas environmental regulatory programs offer an opportunity for all interested stakeholder groups to provide input and recommendations on a state's regulatory program. They also provide value to the reviewed programs. In some cases, recommendations have served as a catalyst for state legislative changes which have resulted in increased resources and technology improvements for the regulatory program. Highlighting program strengths in program review reports provides a means for sharing successful ideas between states' programs. Improvements in state regulatory programs enhances protection of human health and the environment. Voluntary improvements in state regulatory programs negates the need for federal regulations for $\mathrm{E} \& \mathrm{P}$ waste management. 


\section{Publications}

Published during the performance period of the DOE Interagency Agreement.

1. Guidelines for State Reviews available at http://www.strongerinc.org $/$ media/news.asp?Newsid=26

2. $\quad$ Rules of Participation available at http://www.strongerinc.org/pdf/Participation.pdf

3. New Mexico Follow-up and Supplemental Review available at http://www.strongerinc.org/pdf/NMfinal.pdf

4. California Follow-up and Supplemental Review available at http://www.strongerinc.org/pdf/CAfinal.pdf

5. West Virginia Follow-up and Supplemental Review available at http://www.strongerinc.org/pdf/WVFinal.pdf

6. Michigan State Review available at http://www.strongerinc.org/pdf/MIfinal.pdf

7. Virginia State Review available at http://www.strongerinc.org/pdf/Final\%20Virginia\%20Report.pdf

8. Louisiana Follow-up Review available at http://www.strongerinc.org/pdf/Final\%20LA\%20Report.pdf

9. Texas Follow-up and Supplemental Review available at http://www.strongerinc.org/pdf/TX_Final_Report.pdf

10. Pennsylvania Follow-up and Supplemental Review available at http://www.strongerinc.org/pdf/Revised\%20PA\%20Final\%20Report.pdf

11. Oklahoma Follow-up and Supplemental Review

12. Ohio Follow-up and Supplemental Review

13. Indiana Follow-up and Supplemental Review

Reports of reviews prior to 2001 are available through IOGCC at http://www.iogcc.state.ok.us/

\section{LIST OF ACRONYMS AND ABBREVIATIONS}

DOE U.S. Department of Energy

E\&P Oil and Gas Exploration and Production

EPA U.S. Environmental Protection Agency

RCRA Resource Conservation and Recovery Act

STRONGER State Review of Oil and Natural Gas Environmental Regulations, Inc. 